\title{
Multidrug Resistance and Plasmid Profile of Staphylococcus Aureus and Escherichia Coli Isolated From Patients Attending Urology Clinic, Dalhatu Araf Specialist Hospital (DASH) Lafia, Nasarawa State, Nigeria
}

\author{
Abdullahi Sani Ramalan ${ }^{1}$, Joseph Fuh Nfongeh ${ }^{1}$, Mojisola Christiana Owoseni ${ }^{1}$, Ya'aba Yakubu ${ }^{1,2^{*}}$ \\ ${ }^{1}$ Department of Microbiology, Federal University of Lafia, Nasarawa State, Nigeria \\ ${ }^{2}$ Department of Microbiology and biotechnology National Institute for Pharmaceutical Research and Development (NIPRD) Abuja, Nigeria
}

DOI: $\underline{10.36348 / \mathrm{sjpm} .2020 . \mathrm{v} 05 \mathrm{i} 08.001}$

| Received: 30.07.2020 | Accepted: 07.08.2020 | Published: 13.08.2020

*Corresponding author: Ya'aba Yakubu

\section{Abstract}

Urinary tract infections (UTIs) remain the most common infections that affect all age groups worldwide. This study was aimed at determining the multidrug resistance (MDR) and plasmid profile of Staphylococcus aureus and Escherichia coli among patients attending Urology Clinic of Dalhatu Araf Specialist Hospital (DASH) Lafia, Nasarawa State, Nigeria. A total of two hundred and two (202) urine samples were collected in sterile containers and analyzed using standard microbiological techniques. Antibiotic susceptibility testing of the isolates was carried out using standard laboratory guidelines. Of the 202 samples analysed, 104 (51.4\%) had significant bacteriuria. Staphylococcus aureus showed high resistance to Ampicillin, Amoxicillin, and Norfloxacin while E. coli was highly resistant to Rifampicin, Ampicilin, Ciprofloxacin and Ofloxacin. A total of $19(18.27 \%)$ isolates were resistant to more than two different classes of antibiotics i.e. MDR. Out of the 19 MDR isolates, $11.29 \%$ were $S$. aureus while $19.35 \%$ were $E$. coli. These isolates were carrying plasmid for MDR ranging from 2500 base pair (bp) to 6000bp for $S$. aureus while $11,849 \mathrm{bp}$ for E. coli. Plasmids were therefore implicated to be responsible for drug resistance in most of the UTIs. Therefore, proper hygiene by individuals and public awareness policies by government agencies should be encouraged; and antibiotics for the treatment of UTIs should be based on these current antibiogram results.

Keywords: Urinary Tract Infections, Multidrug Resistance, Plasmid Profile, Staphylococcus aureus, Escherichia coli.

Copyright @ 2020: This is an open-access article distributed under the terms of the Creative Commons Attribution license which permits unrestricted use, distribution, and reproduction in any medium for non-commercial use (NonCommercial, or CC-BY-NC) provided the original author and sources are credited.

\section{INTRODUCTION}

There are reports of illness and death related to increased rates of urinary tract infections caused by uropathogens and this results in increased rates of most hospital visits and related nosocomial infection of the beings $[1,2]$. There could be numerous causes of disease in beings, but infectious diseases are set whenever a pathogenic microbe is able to infiltrate host tissue, settle and cause harm to the tissues. The urinary tract or urinary system is made up of those structures or organs related with the production, transport, storage and discharge (voiding) of urine and infestation of any of its part by a pathogenic microorganism is called Urinary Tract Infection (UTI). These structures include: kidney, ureter, bladder, urethra, nerve cells and other structures $[3,4]$.

Some of the clinical signs or symptoms of UTI
includes burning feelings during urination
(micturation), frequency in micturation or incontinence,
loin back or abdominal pains, turbid or dark or

sometimes bloody urine, or even an unusual-smelling of urine accompanied by feverish condition. It is also possible to have nausea or vomiting sometimes when chronic stage is attained as reported by the National Kidney and Urologic Diseases Information Clearinghouse (NKUDIC) [5]. These pathogenic microbes could be bacteria, fungi, virus or even parasites [6]. Bacteria have been documented as the main uropathogen affecting the urinary tract [7].

An estimated people of more than 100 million world-wide came down with UTI annually [8]. This is perceived to be a burden to the nations and persons affected [9]. An approximated 1 billion US dollars is spent annually on cases of more than 8 million hospitalizations from emergency, hospital clinics and office visits in the United States [10]. The epidemiology of pathogenic UTI cases is considerably changing, claiming lives of persons owed to its development of resistance $[11,12]$. Virulence issues for UTI caused by $S$. aureus and E. coli include the specific surface 
associated adhesions they posses, toxins they produce, polysaccharides contain on their cell wall, locomotory organelles and siderophores [13,14].

Predisposing factors to UTIs include: sexual intercourse with infected parson [15], gender [16], urinary catheters $[17,18]$, inheritance, disease condition such as diabetes [15], uncircumcised persons [19], enlarged prostates [20], spinal cord injury due to use of catheter for voiding during urethral dysfunction [21]. Preceding exposure to UTI is also known to be a predisposing factor [22]. Underprivileged personal hygiene and cultural habits are also a predisposing factor for UTI [23].

The diagnosis of UTI is based on urinalysis, dipstick leukocyte esterase test for detecting blood in urine $\left(10 \mathrm{WBC} / \mathrm{mm}^{3}\right)$; and the presence of Nitrite in a urine sample is an indication of UTI [24]. Nevertheless, urine microscopy, culture and sensitivity are the widely used and most preferred methods for diagnosis.

There is a global interest with regards to antimicrobial resistance in pathogenic organisms, with particular emphasis on $S$. aureus and E. coli [25]. There is the need to intensify efforts aimed at knowing the causative agents of UTIs in relation to their antimicrobial activities to the readily available drugs as this will help in the appropriate prescription policies, choice and use of antimicrobial agents within a locality [26]. The societies are now uninterruptedly faced with multidrug resistant specie of organisms causing UTI [27]. This has been well-known to be a major problem and a major risk to health globally [28]. The multidrug resistant challenge has also been documented in Nigeria [29]. The unprincipled use and management of antimicrobial agents among patients and healthcare workers have led to an increase in microbial resistance among uropathogens with a resulting spread to other antibiotic susceptible organisms causing a serious health impediment $[30,31,32]$. The age, health status of an individual and the resistant nature of the species determines the nature of the infection [33]. Several cases of ill-health and renal abnormality or failure have been attributed to $S$. aureus and $E$. coli infections among urology patients [34].

Determination of plasmid is very imperative in epidemiological studies. Besides, it has been proved to be the earliest DNA-based method applied for analyzing resistance pattern, frequency and probable future status of the resistance in relation to certain parameter [35]. Molecular identification of genes offers the feature information about the pathways followed for resistance, effectiveness of bacteria to drive these possessions in long run and genotypic view of resistance whereas curing of plasmid and transfer explains frequency of resistance transferred to the extent of emerging resistance in novel strains [35].
Nevertheless, there are limited study on the multidrug resistance and plasmid profile of $S$. aureus and $E$. coli from UTI cases in this study area were known to authors, although, there was report on its prevalence in this study area [12]. Thus, this informed the choice of research area and the health facility. Therefore, this research work was aimed to examined the multidrug resistance and plasmid profile of Staphylococcus aureus and Escherichia coli isolated from patients attending Urology clinic of Dalhatu Araf Specialist Hospital (DASH) Lafia, Nasarawa State, Nigeria. At the end of this study the bacteriuria status of the patients will be ascertained, susceptibility of the isolates from the urine samples of the patients will also be known and this will give rise to determine the plasmid profile embedded in those multidrug resistant organisms among the isolates.

\section{MATERIALS AND METHODS Study Area}

The study was carried out in Lafia. Lafia is situated in the North central part of Nigeria, lying at latitude $8^{\circ} 29^{\prime} 30^{\prime \prime}$. It has a total of 330,712 inhabitants according to $[36,37]$. In another report by World Population Review (WPR), [38], Lafia has a population of $127,236$.

\section{Ethical Consideration and approval}

Ethical approval for this study was obtained from Dalhatu Araf Specialist Hospital ethical committee with protocol approved number DASH/L/ADM/0340.

\section{Consent}

The consent of each patient was soughed and consent forms were signed to serve as an agreement of participation in the research work.

\section{Collection of Samples}

After duly informing the patients on how to collect their urine samples into sterile containers, two hundred and two (202) mid-stream urine specimens were collected from patients attending Urology Clinic of the hospital. The recruitment of the research patients was randomized. Samples were collected from patients between $6 \mathrm{a} . \mathrm{m}$. and 9a.m. into sterile bottles. The sample container caps were tightly closed then stored in ice packed containers for onward transport to the laboratory. To evade cross contamination during sampling, sterile gloves and forceps were used. The samples were immediately transported to the Microbiology laboratory of Federal of University, Lafia, for microbiological analysis.

\section{Isolation and Identification of Test Organisms}

The urine from the sterile sample containers were aseptically streaked onto Mannitol Salt Agar (MSA) and Eosin Methylene Blue Agar (EMBA) plates and incubated at $37^{\circ} \mathrm{C}$ for overnight as described by Cheesbrough, [39]. Greenish metallic sheen colonies 
that grew on EMBA were carefully chosen as E. coli while those appearing yellowish with color change on MSA plates to pink color indicating fermentation of sugar were carefully chosen as $S$. aureus. The probable isolates were identified through microscopy (Gram stain) and biochemical tests particularly catalase, coagulase, indole and citrate tests respectively. The isolates were then stored on a nutrient agar slant for subsequent analysis.

\section{Antibiotic Susceptibility Testing}

The antibiotic susceptibility tests of $S$. aureus and E. coli isolates were carried out as done by Kirby Bauer disc diffusion method and modified by Helen and Jenifer, [40]. Briefly, 3 pure colonies of the isolated species from the patients' urine samples were inoculated into $5 \mathrm{ml}$ sterile normal saline $(0.85 \% \mathrm{w} / \mathrm{v}$ $\mathrm{NaCL}$ ) and the turbidity of the bacteria solution was adjusted to equivalent that of $0.5 \mathrm{McFarland}$ 's standard solution $\left(0.5 \mathrm{ml}\right.$ of $1.172 \% \mathrm{w} / \mathrm{v} \mathrm{BaCl}_{2} .2 \mathrm{H}_{2} \mathrm{O}$ into $99.5 \mathrm{ml}$ of $1 \% \mathrm{w} / \mathrm{v} \mathrm{H}_{2} \mathrm{SO}_{4}$ ). Sterile swab sticks soaked in the standardized bacterial suspension were streaked onto already prepared Mueller-Hinton media and the antibiotic disks were then aseptically embedded onto the center of the inoculated Mueller-Hinton media. The effectiveness of the antibiotics against the test organisms were checked for either resistance, intermediate resistance or susceptible after comparing the inhibition zone diameter of each antibiotic by its corresponding clinical zone diameter break point ( $\mathrm{mm})$. The antibiotics tested against the isolates of $S$. aureus and $E$. coli were: Ofloxacin $(10 \mu \mathrm{g})$, Levofloxacin (10 $\mu \mathrm{g})$, Nalidixic acid (30 $\mu \mathrm{g})$, Ciprofloxacin $(10 \mu \mathrm{g})$, ampicilllin/clavulanic acid (30 $\mu \mathrm{g})$, Gentamycin (10 $\mu \mathrm{g})$, Cotrimoxazole $(30 \mu \mathrm{g})$, Streptomycin $(30 \mu \mathrm{g})$, Cefalexin $(10 \mu \mathrm{g})$, Ampicillin $(30 \mu \mathrm{g})$, Ciprofloxacin $(10 \mu \mathrm{g})$, Norfloxacin $(10 \mu \mathrm{g})$, Gentamycin $(10 \mu \mathrm{g})$, Streptomycin $(30 \mu \mathrm{g})$, Amoxicillin $(20 \mu \mathrm{g})$, Erythromycin $(30 \mu \mathrm{g})$, Rifampicin (20 $\mu \mathrm{g})$, Chloramphenicol $(30 \mu \mathrm{g})$, Ampicillin $(20 \mu \mathrm{g})$, and Levofloxacin $(20 \mu \mathrm{g})$ as described by Godwin et al. [41]. Staphylococcus aureus (NCTC 6571) and Escherichia coli (NCTC 10418) obtained from Department of Microbiology and Biotechnology, National Institute for Pharmaceutical Research and Development (NIPRD) were used as control.

\section{Plasmid DNA Analyses of Isolates}

Plasmid DNA analyses of the multi-drug resistant isolates were performed at Applied Biotechnology International Nigeria Limited (ABINL) Abuja, Nigeria.

\section{Extraction of Plasmid DNA Using Spin-Column Protocol}

Plasmid DNA extractions were done as described by Bimboim and Doly, [42] and Akinjogunla and Enabulele, [43] using Bacterial plasmid DNA miniprep $^{\mathrm{TM}}$ (Zymo Scientific, USA). Each isolate was inoculated into $10 \mathrm{ml}$ Luria-Bertani (LB) broth and incubated for 16 hours at $37^{\circ} \mathrm{C}$ while shaking at 200250rpm. The bacterial culture was harvested by centrifugation at $8000 \mathrm{rpm}$ in a microcentrifuge for two minutes at room temperature. The supernatant was decanted and all remaining medium removed. The pelleted cells were re-suspended in $250 \mu \mathrm{L}$ of resuspension solution and transferred to microcentrifuge tube for another round of centrifugation.

Exactly $250 \mu \mathrm{L}$ of lysis solution was added and mixed thoroughly by inverting the tube 4-6 times until solution was viscous and slightly clear. This was followed by adding $350 \mu \mathrm{L}$ of neutralization solution and mixed by inverting the tube. The samples were centrifuged at $10,000 \mathrm{rpm}$ for five minutes to pellet cell debris and chromosomal DNA. The supernatant was transferred to Gene JET spin column by decantation.

The samples were centrifuged within a minute and the supernatant were discarded. A solution of 500 $\mu \mathrm{L}$ was added to the column and centrifuged within a minute, flow-through were discarded and the column placed back into collection tube. The wash procedure was repeated to avoid residual ethanol in plasmid preps. The Gene JET spin column was transferred into fresh $1.5 \mathrm{~mL}$ microcentrifuge tube and $50 \mu \mathrm{l}$ of elution buffer was added to the centre of the column to elute plasmid DNA. This was incubated for 2 minutes at room temperature and centrifuged for two minutes. The cleansed plasmid DNA was stored at $-20^{\circ} \mathrm{C}$ for further study.

\section{Plasmid Curing}

The isolates that were multiple drug resistant due to plasmid bands were exposed to plasmid curing using the method described by Akinjogunla and Enabulele, [43]. One $(0.1) \mathrm{mg} / \mathrm{mL}$ of ethidium bromide was added into $100 \mathrm{~mL}$ of Luria Bertaru broth. The resolution was autoclaved at $121{ }^{\circ} \mathrm{C}$ at $15 \mathrm{psi}$ for 15 min. An overnight culture of the sample was standardized with $0.5 \mathrm{McF}$ arland standard and $0.5 \mathrm{~mL}$ of the standardized suspension was pipette using pasteur pipette into $100 \mathrm{~mL}$ sterile Luria Bertaru broth. The solution was incubated at $37^{\circ} \mathrm{C}$ for $4 \mathrm{hrs}$. After the incubation period, the isolates were re-inoculated into a sterile nutrient broth and incubated for $24 \mathrm{hrs}$.

\section{Quantification of the Extracted plasmid DNA}

The extracted plasmids DNA were quantified using the Nanodrop 1,000 spectrophotometer. This was done by placing a drop i.e. approximately $2 \mu \mathrm{L}$ on the sample space and analysed using the Nanodrop 1,000 software [9].

\section{Detection of Number and Sizes of Plasmid DNA (Agarose Gel Electrophoresis)}

One percent $(1.0 \%)$ agarose gel was used to detect the plasmid DNA portions. This was prepared by combining $1 \mathrm{~g}$ agarose in ten times concentration of trisborate ethylenediaminetetraacetic acid $(10 \mathrm{~mL} \mathrm{10XTB-}$ 
EDTA) buffer and $90 \mathrm{ml}$ sterile distilled water in 250 $\mathrm{mL}$ beaker flask and heating in a microwave for 2 minutes until the agarose was dissolved [44].

Exactly, $0.5 \mu \mathrm{L}$ of Ethidium bromide was added to the dissolved agarose solution with swirling to mix. The gel was then poured onto a mini horizontal gel electrophoresis tank and casting combs were introduced. This was allowed to gel for thirty minutes. The casting combs were cautiously removed after the gel had solidified completely. One times concentration (1X) Tris Borate EDTA (TBE) buffer was added to the reservoir until it covered the agarose gel. Precisely 0.5 $\mu \mathrm{L}$ of gel tracking dye (bromophenol blue) was added to $20 \mu \mathrm{L}$ of each sample with gentle mixing. Twenty microliters volume of the sample was loaded onto the wells of the gel, the mini horizontal electrophoresis gel setup was covered and electrodes connected. Electrophoresis was performed at $100-200 \mathrm{~mA}$ for one hour. At the completion of electrophoresis, the gel was removed from the buffer and viewed under UVtransilluminator. The band pattern of DNA portions was photographed with a Polaroid camera and documented using electrophoresis gel documentation system [44].

\section{STATISTICAL ANALYSIS}

The data obtained were analysed using SPSS (version 20) statistical software. Standard simple statistical tools such as percentile were used to interpret some of the findings in tabular forms.

\section{RESULTS}

The morphological and biochemical characteristic of the isolates revealed that Staphylococcus aureus appeared yellow on Mannitol Salt Agar (MSA) with fermentation of sugar indicated by colour variation of the medium and were seen to be Gram-positive cocci during microscopy with biochemical reactions been positive for catalase and coagulase tests. Escherichia coli appeared green metallic sheen on Eosin Methylene Blue Agar (EMBA) and were seen to be Gram negative bacilli with biochemical reactions on indole test positive with red surface layer observed while citrate test was negative with no colour variation of the agar slant and VogesProsauer neagative (Table 1).

Table-1: Cultural, Morphological and Biochemical Characteristics of Isolates from urine samples of patients attending Urology Clinic of DASH Lafia, Nasarawa State, Nigeria

\begin{tabular}{|l|l|l|l|l|l|}
\hline \multirow{2}{*}{ Cultural character } & \multicolumn{3}{|l|}{ Morphological character } & Biochemical character & Inference \\
\cline { 2 - 6 } & Gram reaction & Morphology & ind cit vp cat coag & S. aureus \\
\hline $\begin{array}{l}\text { Pinkish colony } \\
\text { on MSA }\end{array}$ & + & cocci + & \\
\hline $\begin{array}{l}\text { Greenish metallic } \\
\text { sheen colony on } \\
\text { EMBA }\end{array}$ & - & Rod & +-2 coli & \\
\hline
\end{tabular}

Key: $+=$ positive, - = negative, ind $=$ Indole test, cit $=$ Citrate test, $v p=$ Voges-Prosauer test, cat $=$ Catalase test, cog $=$ coagulase test

The bacterial count of the isolates in relation to patients analyzed indicated a total number of 202 patients analyzed during the research exercise with high rate of Staphylococcus aureus infection (30.69) than Escherichia coli infection (20.79). The highest percentage rate recorded was 17 (24.14) in S. aureus and 11 (31.43) in E. coli. Escherichia coli showed higher resistance value than $S$. aureus. Resistance to the antibiotics analysed was higher in E. coli 12 (28.50) than in $S$. aureus (11.29), with a highest resistance rate of 3 (4.69) in S. aureus and 4 (9.52) in E. coli respectively, as shown on table 2 .

Table-2: Bacterial Count of the Isolates in Relation to patients analysed

\begin{tabular}{|c|c|c|c|c|}
\hline Patients & \multicolumn{2}{|c|}{ Bacterial Isolates (CFU $\geq 105 / \mathrm{mL})$} & \multicolumn{2}{|c|}{ No. of Resistant isolates (CFU $\geq 105 / \mathrm{mL}$ ) } \\
\hline & S. aureus (\%) & E. coli $(\%)$ & S. aureus (\%) & E. coli $(\%)$ \\
\hline 29 & $7(24.14)$ & $7(24.14)$ & $2(3.13)$ & $1(2.38)$ \\
\hline 40 & $17(42.50)$ & $8(20.00)$ & $3(4.69)$ & $1(2.38)$ \\
\hline 35 & $12(34.29)$ & $11(31.43)$ & $1(1.56)$ & $4(9.52)$ \\
\hline 35 & $11(31.43)$ & $8(22.86)$ & $1(1.56)$ & $4(9.52)$ \\
\hline 25 & $7(28.00)$ & $4(16.00)$ & - & - \\
\hline 38 & $8(21.05)$ & $4(10.35)$ & - & - \\
\hline 202 & $62(30.69)$ & $4(10.35)$ & $7(11.29)$ & $7(11.29)$ \\
\hline
\end{tabular}

Key: No. $=$ number, $\%=$ percentage, $\mathrm{CFU}=$ Colony Forming Unit, $\mathrm{mL}=$ millilitres.

\section{Antibiotic Susceptibility among Staphylococcus aureus and Escherichia coli}

The antibiotic susceptibility of $S$. aureus showed that Levofloxacin was most effective against the test organism 46 (74.19\%), Norfloxacin been most intermediate resistance 22(35.48\%) and Ampicillin had the most resistance result among the organisms tested $18(29.03 \%)$. Of the total antibiotics analyzed against $E$. coli, Ciprofloxacin had the highest proportion outcome 27 (64.29\%) while Amoxycillin/clavulanic acid showed 
highest predominance of intermediate result 14 $(33.33 \%)$. From the analysis, Rifamycin showed the highest incidence of drug resistance 15 (35.71) against the isolate as shown on table 3 .

Table-3: Antibiotic Susceptibility Profile among Staphylococcus aureus and Escherichia coli isolates

\begin{tabular}{|c|c|c|c|c|c|c|}
\hline \multirow{2}{*}{ Antibiotics $(\mu \mathrm{g})$} & \multicolumn{3}{|c|}{ Staphylococcus aureus } & \multicolumn{3}{|c|}{ Escherichia coli } \\
\hline & $\begin{array}{c}\text { Susceptible } \\
(\%)\end{array}$ & $\begin{array}{c}\text { Intermediate } \\
(\%)\end{array}$ & $\begin{array}{c}\text { Resistant } \\
(\%)\end{array}$ & $\begin{array}{c}\text { Susceptible } \\
(\%)\end{array}$ & $\begin{array}{c}\text { Intermediate } \\
(\%)\end{array}$ & $\begin{array}{c}\text { Resistant } \\
(\%)\end{array}$ \\
\hline CPX (10) & $44(70.96)$ & $6(9.68)$ & $13(20.97)$ & $27(64.29)$ & $1(2.38)$ & $13(30.96)$ \\
\hline LEV (20) & $46(74.19)$ & $12(19.35)$ & $5(8 . .06)$ & - & - & - \\
\hline RD (20) & $38(61.29)$ & $20(32.26)$ & $4(6.45)$ & - & - & - \\
\hline$(30)$ & $39(62.90)$ & $13(20.97)$ & $10(16.13)$ & $26(61.90)$ & $7(16.67)$ & $6(14.29)$ \\
\hline NB (10) & $27(43.55)$ & $22(35.48)$ & $14(22.58)$ & - & - & - \\
\hline E $\quad(30)$ & $34(54.84)$ & $21(33.87)$ & $8(12.90)$ & - & - & - \\
\hline CN (10) & $35(56.45)$ & $19(30.65)$ & $6(9.68)$ & $23(54.76)$ & $13(30.95)$ & $6(14.29)$ \\
\hline $\mathrm{CH} \quad(30)$ & $33(53.23)$ & $17(27.42)$ & $13(20.97)$ & - & - & - \\
\hline APX (20) & $26(41.94)$ & $19(30.65)$ & $18(29.03)$ & - & - & - \\
\hline AMX (30) & $34(54.84)$ & $13(20.97)$ & $16(25.80)$ & - & - & - \\
\hline OFX (10) & & & & $22(52.38)$ & $8(19.05)$ & $12(28.57)$ \\
\hline PEF (10) & & & & $15(35.71)$ & $12(28.57)$ & $15(35.71)$ \\
\hline NA $\quad(30)$ & & & & $19(45.24)$ & $11(26.19)$ & $12(28.57)$ \\
\hline AU (30) & & & & $22(52.38)$ & $14(33.33)$ & $6(14.29)$ \\
\hline SXT (30) & & & & $25(59.52)$ & $8(19.05)$ & $10(23.81)$ \\
\hline CEP (10) & & & & $22(52.38)$ & $9(21.43)$ & $11(26.19)$ \\
\hline $\begin{array}{ll}\mathrm{PN} & (30) \\
\end{array}$ & & & & $17(40.48)$ & $11(26.19)$ & $13(30.95)$ \\
\hline
\end{tabular}

Key: $\mathrm{CPX}=$ ciprofloxacin, $\mathrm{LEV}=$ levofloxacin, $\mathrm{RD}=$ rifampicin, $\mathrm{S}=$ streptomycin, $\mathrm{NB}=$ norfloxacin, $\mathrm{E}=$ erythromycin, $\mathrm{CN}=$ gentamycin, $\mathrm{CH}=$ chloramphenicol, $\mathrm{APX}=$ ampicillin, $\mathrm{AMX}=$ amoxil. $\mathrm{CPX}=$ ciprofloxacin, $\mathrm{SXT}=$ septrin, $\mathrm{PN}=$ ampicillin, $\mathrm{OFX}=$ triviid, $\mathrm{CEP}=$ ceporex, $\mathrm{NA}=$ nalidixic acid, $\mathrm{S}=$ streptomycin, $\mathrm{PEF}=$ peflacin, $\mathrm{CN}=$ gentamycin, $\mathrm{AU}$ = Amoxycillin/clavulanic acid, - = not applicable.

Plasmid Variation among Multi-drug Resistant Staphylococcus aureus isolates

The plasmid disparity of resistant $S$. aureus isolate showed various plasmids with varying sizes (bands) ranging from $2500 \mathrm{bp}$ to $6000 \mathrm{bp}$. All the isolates presented only one plasmid except for isolate $\mathrm{S}_{13}{ }^{4}$ which presented 3 bands with different sizes ranging from 3000bp, 3600bp and 6000bp (Plate 1).

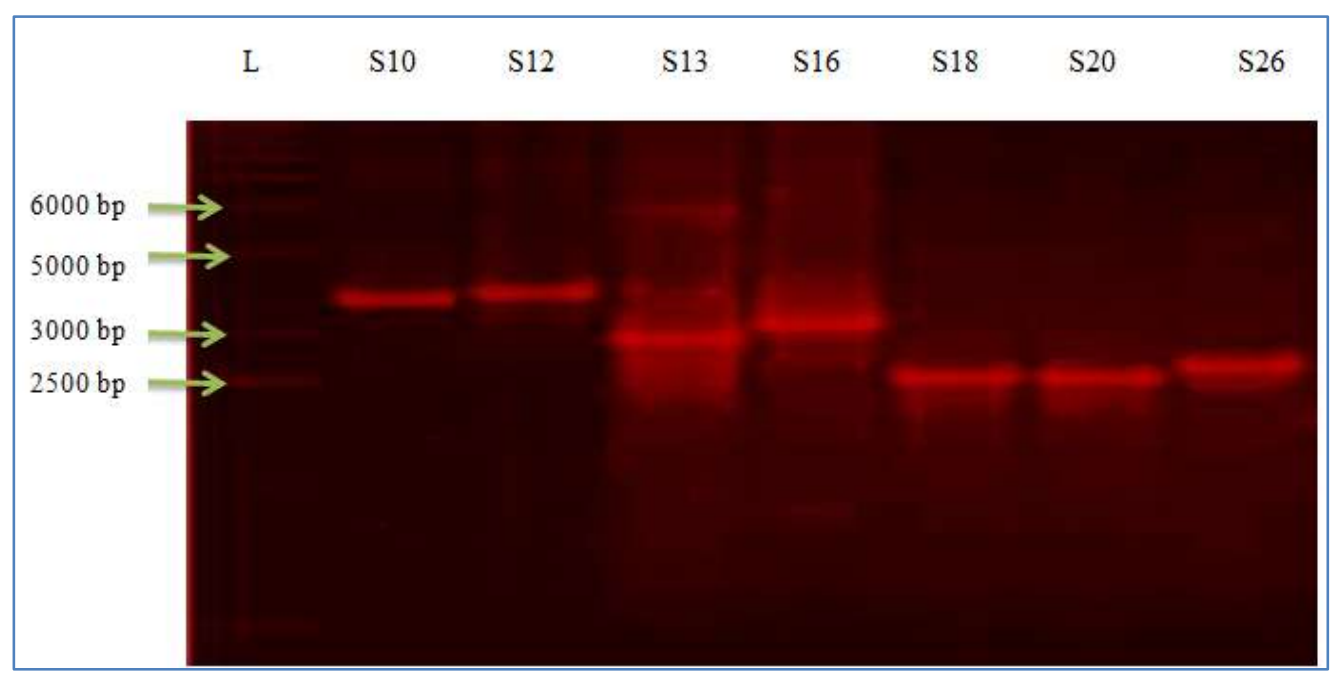

Plate-1: Agarose Gel Electrophoresis of Plasmid DNA from the MDR Staphylococcus aureus Isolates

Lane L: Supercoil DNA ladder composed of DNA fragments (in base pairs).

\section{Plasmid Variation among Multi-drug Resistant Escherichia coli Isolates}

The plasmid disparity of multidrug resistant $E$. coli from this study revealed only one band with plasmid size of 11, 849bp. The occurrence of Plasmids Resistant among Escherichia coli Isolates is shown in Table 7 and agarose gel electrophoresis of plasmid DNA from the MDR Escherichia coli I isolates (Plate 2). 


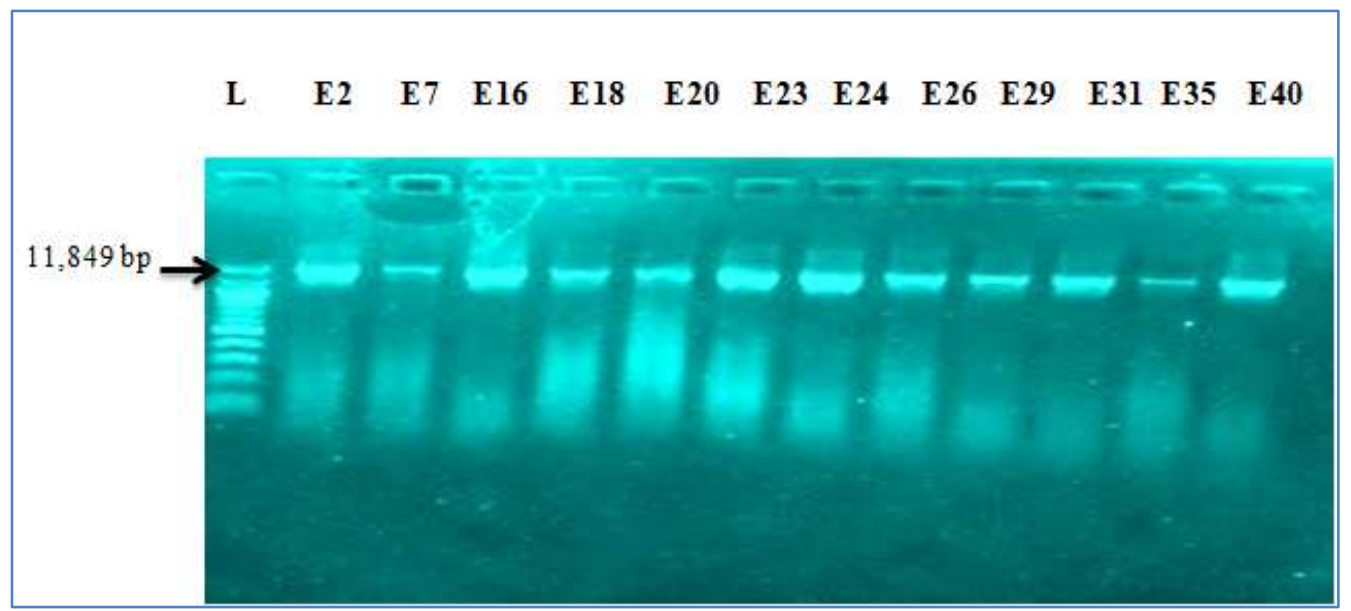

Plate-2: Agarose Gel Electrophoresis of Plasmid DNA from the MDR Escherichia coli Isolates

Lane L: Supercoil DNA Ladder Composed of DNA Fragments (In Base Pairs).

\section{DISCUSSION}

Urinary tract infection is a major cause of morbidity and mortality. The findings from this work revealed the bacteriuria status of the patients indicated a high rate of Staphylococcus aureus infection (30.69\%) than Escherichia coli infection (20.79\%). This could be attributed to contamination of the hand or of the skin surface covering the genetalia. The uropathogens isolated in this research work exhibited high susceptibility rate to Levofloxacin, Ciprofloxacin, and Streptomycin as implicated in $S$. aureus then Ciprofloxacin, Streptomycin, and Septrin implicated in E. coli. This result could be as a result of not abusing drugs by the patients or the organisms had not started developing resistance to those antibiotics within the study population. A total number of 19 (18.27\%) isolates were recorded resistance for more than two antibiotics (MDR). This is in agreement with the research done by Haruna et al., [45] and Alabi et al., [46]. The high percentage resistance of the isolates in this study is not shocking as it possibly indicates that some of the resistance was as a result of antibiotic misuse or abuse or possibly that the isolates are carrying plasmids for antibiotics resistance as it was also reported by Ngwai et al., [47]. This is also similar to work carried out by Eugene et al., [48] who also documented that resistance to antibiotics by the bacteria might be due to various reasons such as gross misuse of these drugs, over production of target sites, inactivation of the antibiotic, alteration of membrane permeability and spontaneous mutation through DNA transfer amongst others in Uyo city in Akwa Ibom State, Nigeria.

In this research work, the plasmid analysis revealed that multiple drug resistant $S$. aureus isolates harbor one or more plasmids with different molecular weights ranging from 2500 base pair (bp) to 6000bp while multiple resistant $E$. coli. Isolates harbor one single plasmid size type of $11,849 \mathrm{bp}$ which denoted that their resistance is not chromosomal borne. This is in agreement with work carried out by Van Hal et al., [49] in which they documented that MDR plasmids might be acquired by susceptible bacteria through treatment with antibiotics that can induced and hand-picked for horizontal gene transfer. It was also reported by other scientists that the possession of plasmids may be through careful pressure from increased use and misuse of antimicrobial agents [50]. However other scientists assumed that the acquisition of resistance may be due to chromosomal mutations or plasmids that are capable of transferring from one strain of organism to another even across the species in addition to environmental influence. Therefore, the gene coding for antibiotics resistance may perhaps either coded on the plasmid and chromosomal DNA [51].

In this research work, multiple antibiotics resistant $S$. aureus that were resistant before plasmid curing developed became sensitive to the prescribed antibiotics after curing with ethidium bromide. Multiple antibiotics resistant Escherichia coli were resistant prior to plasmid curing still retain their resistant to prescribed antibiotics after curing with ethidium bromide. This finding is comparable to the other work carried out by other researchers who reported that plasmid have encoded gene that offers resistance to naturally occurring antibiotics in modest environmental niche $[52,53]$. Similarly, the findings from this study is also in agreement with the work performed by Ojo et al., [54] which documented that resistance exposed by some bacterial isolates such as $S$. aureus, Pseudomonas aeruginosa and Proteus mirabilis are mainly plasmid mediated.

Nevertheless, resistances revealed by some of the bacterial isolates such as Escherichia coli, and $S$. pyogenes are chromosomal mediated. Several other resistances to bacterial organisms that are not owed to plasmid or chromosome might be owed to efflux pump mechanism [55] or other factors such as mutation of gene encoding ribosomal protein which decrease penetrability of the cell envelope in enteric bacteria 
[56]. The bacterial isolates screening with ethidium bromide resultantly propose that the resistance markers were stably lost which is in line with aforementioned studies done by other researchers [57, 58].

\section{CONCLUSION}

Staphylococcus aureus and Escherichia coli are among the bacteria linked to Urinary Tract Infection within Urology clinic patients of DASH, Lafia, Nasarawa State, Nigeria. There is a fearsome upsurge of infections caused by antibiotic-resistant bacteria. The result from this study showed high susceptibility rate of Levofloxacin against $S$. aureus and Ciprofloxacin against $E$. coli while high resistance rate was recorded in Ampicillin against $S$. aureus and Reflacin against $E$. coli respectively. Appropriate public health policy on prescribing and use of antibiotics must be established and implemented based on current antibiogram results. This Study also disclosed that the genetic basis for antibiotic resistance in the study location is not entirely plasmid mediated but it could either be chromosomal mediated or plasmid mediated.

\section{RECOMMENDATIONS}

1. There is the need for proper observation of personal hygiene by individuals such as the use of clean underwear, proper and adequate cleaning after urinating or defecating to help prevent urinary tract infection. There is also the need to wipe front to back and not back to front during cleaning the genital region and the anal openings. This is especially applicable to females.

2. Routine surveillance and monitoring studies should be conducted by government agencies concern as this will help to provide physicians with knowledge about the most effective empirical treatment of UTIs, since drug resistance among pathogens is in circulation in the community and hospital settings.

3. There is the need for collaborative effort between Government agents and private organizations to continuously give public awareness and education on the rationale behind antibiotic use as well as adopting strict national antibiotic policy to regulate the prescription, sale and use of antibiotics in the pharmacies. Indiscriminate prescription and use of antibiotics must be discouraged in both community and hospital settings by Government agencies too.

\section{COMPETING INTERESTS}

Authors declared no competing interests.

\section{ACKNOWLEDGEMENT}

We are sincerely grateful to the management, lecturers and technologists of the Department of Microbiology, Federal University of Lafia. Profound gratitude also goes to Dalhatu Araf Specialist Hospital (DASH) ethical committee for the approval of their health institutions as center for this research work. We also appreciate all the staff of Urology department of this health center for their cooperation and technical supports in the collection of specimens/samples from the patients.

\section{REFERENCES}

1. Morphy, S.C. (2006). Malaria and Global infectious diseases: why should we care? Journal of Virtual Mentor, 8(4):245-50.

2. Najar, M.S., Saldauha, C.L., \& Banday, K.A. (2009). Approach to urinary tract infections. Indian Journal of Nephrology, 19:129-139.

3. Eugene, W.N., Denise, G.A., Evans, C.R. Jr., \& Martha, T.N. (2007). The Urinary System. Microbiology: A Human perspective. $5^{\text {th }}$ edition. 650-668.

4. Otajevwo, F.D. (2013). Urinary tract infection among symptomatic out-patients visiting a tertiary osital based in Midwestern Nigeria. Global Journal of Health Science, 5:17-99.

5. National, K., \& Urologic Diseases Information Clearinghouse (NKUDIC). (2005). Fact sheet: urinary tract infections in adults. National Institute of Health Publication, 6:2097.

6. Wynggaarden, J.B., Smith, L.H., \& Benneth, J.C. (2002). Hospital acquired infections. In: Cecil TextBook of Medicine, $19^{\text {th }}$ edition. By Saunders, W. B'. 123-240.

7. Ebie, M.Y., Kandakai-Olukemi, Y.T., Ayanbadejo, J. \& Tanyigna, K.B. (2001). Urinary tract infections in a Nigerian Military Hospital. Nigerian Journal of Microbiology, 15:31-37.

8. Stamm, W.E., \& Norrby, S.R. (2001). Urinary tract infections: disease panorama and challenges. Journal of Infectious Diseases, 183(1):1-4.

9. Akingbade, O., Balagun, S., Ojo D., Akinduti, P., Okerent Ugba P.O., Nwanze, J.C. \& Okonkwo, O. I. (2014). Resistant plasmid profile analysis of multi-drug resistant Escherichia coli isolated from urinary tract infections in Abeokuta, Nigeria. African Health Sciences, 14(4):821-828.

10. Aiyegoro, O.A., Igbinosa, O.O., Ogunmwonyi, I.N., Ojadjaro, E., Igbinosa, O.E. \& Okoh, A.I. (2007). Incidence of urinary tract infections (UTI) among children and adolescents in Ile-Ife, Nigeria. African Journal of Microbiology Research, 1:1319.

11. Ojiegbe, G.C., \& Nworie, W.C. (2000). Asymtomatic bacteriuria among school pupils in Enugu UrbanAreas. Journal of Medical Science, 9:42-46.

12. Kolawole, A.S., Kolawole, O.M., KendakiOlukemi, T.T., Babatunde, S.K., Durowode, K.A. \& Kolawole, C.F. (2009). Prevalence of Urinary Tract Infections (UTI) among patients attending Dalhatu Araf Specialist Hospital, Lafia, Nasarawa State, Nigeria. International Journal of Medical Sciences, 1:163-167.

13. Ross, V., Schembri, M.A., Ulett, G.C., \& Klemn, P. (2006). Asymptomatic bacteriuria Escherichia coli strain 83972 carries mutation in the Foc locus 
and is unable to express F1c fimbriae. Microbiology, 152:1799-1806.

14. Bien, J., Sokolova, O., \& Bozko, P. (2012). Role of uropathogenic E. coli. International Journal of Microbiology, 3(2):12-20.

15. Nicolle, L.E. (2008). Uncomplicated Urinary tract infections in adults including uncomplicated pyelonephritis. Urology Clinic of North American, 35(1):1-12.

16. Dielubanza, E.J. \& Scheaffer, A J. (2011). Urinary tract infections in women. The Medical clinic of North America, 95(1):27-41.

17. Phipps, S., Lim, Y.N., McClinton, S., Barry, C., Rane, A. \& N'Dow, J. (2006). Short term uriary catheter policy following urogenital surgery in adults. Cochrane Database of Systematic Reviews, 3(2):43-74.

18. Gould, C.V., Umscheid, C.A., Agarwal, R.K., Kuntz, G., \& Pegues, D.A. (2010). Guideline for prevention of catheter -associated urinary tract infections 2009. Infections Control and Hospital Epidemiology, 31(4):319-26.

19. Morris, B.J., \& Wiswell, T.E. (2013). Circumcision and lifetime risk of urinary tract infection: a systematic review and meta-analysis. The Journal of Urology, 189(6):2118-2122.

20. Lane, D. R., \& Takhar, S. S. (2011). Diagnosis and management of urinary tract infection and pyelonephritis. Emergency Medicine Clinics of North America. 29 (3):539-552.

21. Eves, F.J., \& Rivera, N. (2010). Prevention of urinary tract infections in persons with spinal cord injury in home health care. Journal of Home Health Care Nurse, 28(4): 230-241.

22. Moges, F., Genetu, A., \& Mengstu, G. (2003). Antibiotic sensitivity of common bacterial pathogens in urinary tract infection at Gondat Hospital, Ethiopia. East Africa Medical Journal, 79:140-142.

23. Ehinmidu, J.O. (2003). Antibiotic susceptibility pattern of urine bacterial isolates in Zaria, Nigeria. Tropical Journal of Pharmaceutical Research, 2(2):223-228.

24. Sobel, J.O. \& Kaye, D. (2014). Urinary tract infections. In: Mandell, G. L., Bennett, J. E. eds. Principles and practice of infectious diseases, $8^{\text {th }}$ ed. Philadelphia: Elsevier Saunders. 886-913.

25. Chakupurakal, R.A., Sobithadevi, D.N., Chinnappan, S. \& Reynolds, T. (2011). Urinary tract pathogens and resistance pattern. Journal of Clinical Pathology, 63:652-654.

26. El-Astal, Z. (2005). Bacterial pathogens and their antimicrobial susceptibility in Gaza strip, Palestine. Pakistan Journal of Medicine, 20(4):365-370.

27. Reis, A.C.C., Santos, S.R.S., deSouza, S.C., Saldanha, M.G., Pitanga, T.N. \& Oliveira, R.R. (2016). Ciprofloxacin resistance pattern among bacteria isolated from patients with communityacquired urinary tract infection. Revisita do Instituto de Medicina Tropical de SaóPaulo. 58.
28. Kumar, M.S., Lukshmi, V., \& Rajagopalan, R. (2006). Related articles on occurrence of extended spectrum beta- lactamases among Enterobacteriaceae spp. isolated at a tertiary care Institute. India Journal of Medical Microbiology, 24(3):208-11.

29. Timothy, O.O., Olusegun, F.J., Adesola, B.O., Temitayo, A.A., David, F.O. \& Ige, O.O. (2014). Antibiotic resistance pattern of bacteria isolates from cases of urinary tract infections among hospitalized and out-patients at a tertiary health facility in South Western Nigeria. Annual Tropical Medicine and Public Health, 130-135.

30. Rahman, F., Chowdhury, S., Rahman, M., Ahmed, D., \& Hossain, A. (2009). Antimicrobial susceptibility pattern of Gram-negative bacteria causing urinary tract infection. Stamford Journal of Pharmaceutical Science, 2(1):44-50.

31. Arjunan, M., Al-salamah, A. \& Amuthan, M. (2010). Prevalence and antibiotics susceptibility of uropathogens in patients from the rural environment. American Journal of Infectious Disease. 6(2):29.

32. Sharif, S.I., Ibrahim, O.H., Mouslli, L., \& Waisi, R. (2012). Evaluation of self-medication among pharmacy students. American Journal of Pharmacology and Toxicology, 7:135-140.

33. Tong, S.Y., Davis, J.S., Eichenberger, E., Holland, T.L., \& Fowler, V.G. (2015). Staphylococcus aureus infection: epidemiology, pathophysiology, clinical manifestations and management. Clinical Microbiology Reviews, 28(3):603-61.

34. McLaughlin, S.P., \& Carson, C.C. (2004). "'Urinary tract infections in women,', Medical Clinics of North America, 88(2):417-429.

35. Nwoire, A., Madubuko, E.F., Eze, U.A., Oti, W., Azi, R.O., \& Ibiam, G.A. (2013). Incidence of Staphylococcus aureus in clinical specimens in Federal Teaching Hospital. Abakaliki, Ebonyi State. Merit Research Journal of Medicine and Medical Sciences, 1(3):043-046.

36. National Population Census (2006). Retrieved from:

"https://en.wikipedia.org/w/index.php?title=Lafia\& oldid=917958901"Centre for Disease Control and Prevention (CDC) (2015). Urinary tract infection. Archived from the original on February 2016. 1015.

37. Akwa, V.L., Bimbol, N.L., Samaila, K.L., \& Macus, N.D. (2007). Geography Perspective of Nassarawa State. Onaivi Printing and Publishing Company, Keffi, Nigeria. 3-5.

38. World Population Review (WPR). (2019). Population of Cities in Nigeria. Retrieved from: https://worldpopulationreview.com/countries/nigeri apopulation/cities/.Tuesday,15/10/2019:21;18.

39. Cheesbrough, M. (2006). Antibiotics. District laboratory practice in tropical countries, Cambridge University United Kingdom, Part 2.6370. 
40. Helen, S.L., \& Jenifer, L. (2018). Urinary tract infections. Journal of Infectious Diseases, 7:28.

41. Godwin, A.O., Ebele, U.U., Emmanuel, T.A., Aleruchi, C., \& Peter, A. (2018). Incidence and antibiotic susceptibility pattern of E. coli and Staph. aureus isolated from meat pie sold in a Nigerian North Central town, Journal of Medical Sciences, 6(1):21-28.

42. Bimboim, H.C. \& Doly, J. (1979). A rapid alkaline procedure for screening recombinant plasmid DNA. Nucleic Acids Research, 7:1513-1523.

43. Akinjogunla, O.J., \& Enabulele, I.O. (2010). Virulent factors, plasmid and curing analysis of multi-drug resistant Staphylococcus aureus and Coagulase negative Staphylococcus species. Isolated from patients with acute otitis media. Journal of American Science, 6:1022-1033.

44. Moore, D., Dowhan, D., Chory, J., \& Ribaudo, R. K. (2002). Isolation and purification of large DNA fragments from agarose gels. Current Protocol in Molecular Biology, 59:261-2612.

45. Haruna, M.S., Magu, J., Idume, J., Nosiri, C., \& Garba, M.A. (2014). Antibiotic susceptibility of some uropathogenic bacterial isolates from Ahmadu Bello University Teaching Hospital Zaria, Nigeria. Journal of Pharmaceutical and Biological Sciences, 9:20-23.

46. Alabi, O.S., Onyenwe, N.E., Satoye, K.A., \& Adeleke, O.E. (2014). Prevalence of extended beta +lactamase producing isolates from asymptomatic bacteriuria among students in a tertiary institution in Ibadan, Nigeria. Journal of Natural Science, 12:111-4.

47. Ngwai, Y.B., Gyar, S.D., Pennap, G.R.I., Maut, M.D., Ishaleu, D. Corosi, S.M., Nkene, I.H., \& Uzoamaka, N. (2014). Antibiogram of nonesorbitol fermenting $E$. coli isolated from environmental sources in keffi Nigeria. NSUK Journal of Science and Technology. 4(1\&2): 14521467.

48. Eugene, O.T., Ekpo, M.A., Akinjogunla, O.J., \& Idiong, D.F. (2013). Microorganisms associated with acute otitis media diagnosed in Uyo City. Journal of Nigeria Science Researcher, 4(6):560564.
49. Van Hal, S.J., Wiklendi, A., Espedido, B., Ginn, A., \& Iredell, J.R. (2009). Immediate appearance of plasmid mediated resistance to multiple antibiotics upon antibiotics selection: an augument for systematic resistance epidemiology. Journal of Clinical Microbiology, 47:2325-2327.

50. Agbagwa, O.E., Otokunefor, T.V. \& FrankPeterside, N. (2012). Plasmid profile analysis of bacteria isolated from selected Honey samples in Nigeria. Journal of Animal Science Advances, 2:338-343

51. Oleghe, P.O., Odimegwu, D.C., Udotia, E., \& Esimore, C.O. (2011). Multidrug resistance bacterial isolates recovered from herbal medicinal preparations in Southeastern setting, Nigeria. Journal of Rural and Tropical Public Health, 10:70-75.

52. Lipps, G. (2008). Plasmid current research and future trends. Caister Acadamic Press, 97(8):1-9.

53. Kroll, J., Klinter, S., Schneider, C. \& Steinbucheal, A. (2010). Plasmid addition system. Prespective and application of biotechnology. Microbiology Journal of Biotechnology, 3(6):634-657.

54. Ojo, S.K.S., Sargin, B.O. \& Esumeh, F.I. (2014). Plasmid curing analysis of antibiotic resistance in Blactamase producing Staphylococci from wounds and burns patients. Pakistan Journal of Biological Sciences, 17:130-133.

55. Poole, K. (2004). Efflux-mediated multiple resistance in bacteria. Clinical Microbiology and Infection, 10(1):1226.

56. Isenberger, K., Hill, D.W., Jenkins, I.E. and Mager, J.T. (2002). Clinical signs of the emergence of bacterial resistance in the hospital environment. Journal of Applied Microbiology, 92:908-978.

57. Akortha, E.E., \& Flogona, J. (2009). Transfer of gentamycin resistance gene among Enterobacteriaceae isolated from the outpatients with urinary tract infections attending 3 hospitals in Mubi, Adamawa State. Scientific Research Essay, 4:745-752.

58. Gad, G.F.M., Abd El-Ghafar, A.E., El- Domany, R.A., \& Hashem, Z.S. (2010). Epidemiology and antimicrobial resistance of Staphylococci isolated from different infectious diseases. Brazil Journal of Microbiology, 41:333-344. 